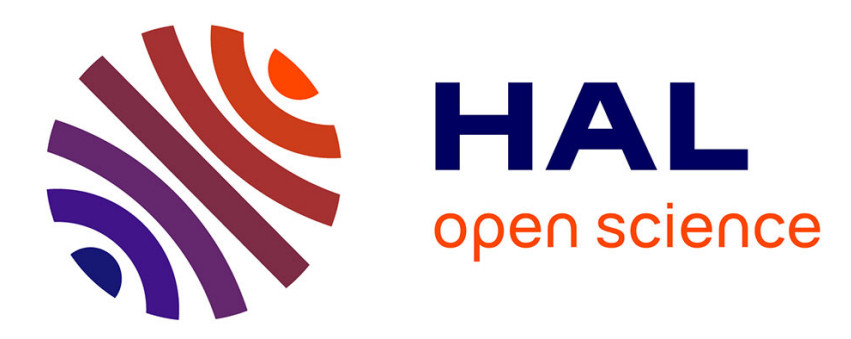

\title{
Labour Productivity and Rice Production in Bangladesh: A Stochastic Frontier Approach
}

Sheikh Selim

\section{To cite this version:}

Sheikh Selim. Labour Productivity and Rice Production in Bangladesh: A Stochastic Frontier Approach. Applied Economics, 2011, pp.1. 10.1080/00036846.2010.515203 . hal-00665453

\section{HAL Id: hal-00665453 \\ https://hal.science/hal-00665453}

Submitted on 2 Feb 2012

HAL is a multi-disciplinary open access archive for the deposit and dissemination of scientific research documents, whether they are published or not. The documents may come from teaching and research institutions in France or abroad, or from public or private research centers.
L'archive ouverte pluridisciplinaire HAL, est destinée au dépôt et à la diffusion de documents scientifiques de niveau recherche, publiés ou non, émanant des établissements d'enseignement et de recherche français ou étrangers, des laboratoires publics ou privés. 


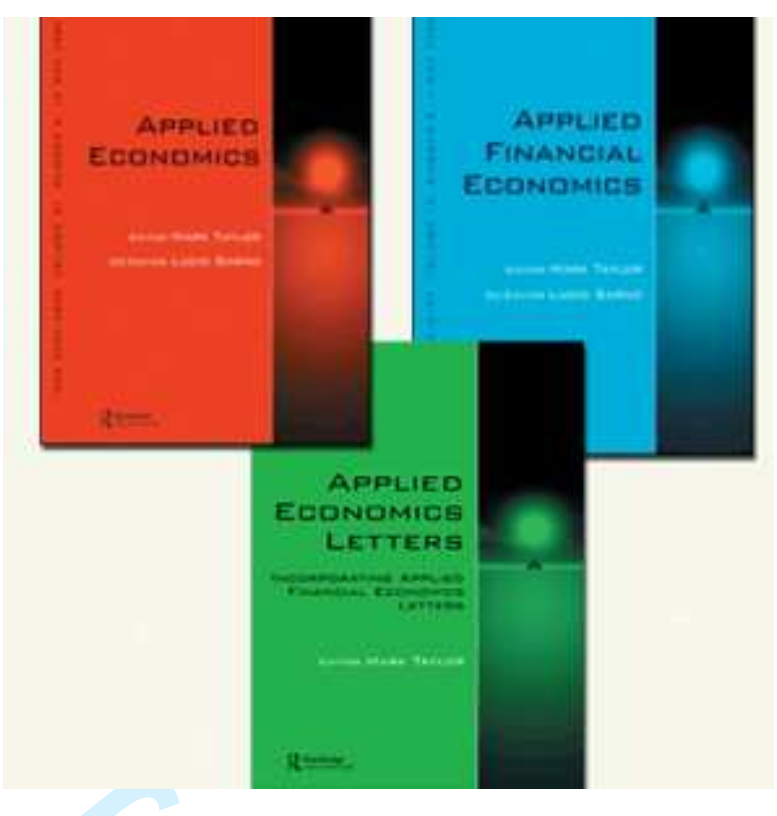

\section{Labour Productivity and Rice Production in Bangladesh: A Stochastic Frontier Approach}

\begin{tabular}{|r|l|}
\hline Journal: & Applied Economics \\
\hline Manuscript ID: & APE-07-0095.R1 \\
\hline Journal Selection: & Applied Economics \\
\hline Author: & 24-Jun-2009 \\
\hline Complete List of Authors: & Selim, Sheikh; Cardiff University, Cardiff Business School \\
\hline & $\begin{array}{l}\text { C33 - Models with Panel Data < C3 - Econometric Methods: } \\
\text { Multiple/Simultaneous Equation Models < C - Mathematical and } \\
\text { Quantitative Methods, C51 - Model Construction and Estimation }< \\
\text { C5 - Econometric Modeling < C - Mathematical and Quantitative } \\
\text { Methods, O13 - Agriculture; Natural Resources; Energy; } \\
\text { Environment; Primary Products < O1 - Economic Development < O } \\
\text { - Economic Development, Technological Change, and Growth, Q12 - } \\
\text { Micro Analysis of Farm Firms, Farm Households, and Farm Input } \\
\text { Markets < Q1 - Agriculture < Q - Agricultural and Natural Resource } \\
\text { Economics }\end{array}$ \\
\hline Keywords: $:$ & $\begin{array}{l}\text { Stochastic Frontier, Non-neutral Frontier, Technical Efficiency, } \\
\text { Bangladesh }\end{array}$ \\
\hline
\end{tabular}




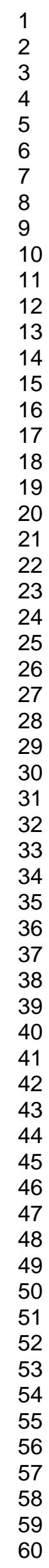

5.) ShholaroNE" $_{\text {Manuscript Central }}$ . 10

25

26

27

29

30

32

33

34

35

36

37

38

41

42

43

45

46

47

48

49

51

52

53

54

55

57

58

59

60 


\title{
Labour Productivity and Rice Production in Bangladesh: A Stochastic Frontier Approach
}

\author{
Sheikh Selim ${ }^{1}$ \\ Cardiff University
}

May, 2009.

\begin{abstract}
:
In this paper we examine the significance of labour productivity and use of inputs in explaining technical efficiency of rice production in Bangladesh. We find that higher labour productivity can stimulate high efficiency gains, but increased use of inputs (except land) induces negative marginal effect on technical efficiency. While more use of land, improved seeds and fertilizers contributes to the rate of labour-productivity induced marginal efficiency gain, any additional labour depresses this rate. Given the agricultural policy reform history in Bangladesh, our findings imply that rather than providing input subsidy or output price support, future reforms should put more emphasis on providing incentives to enhance labour productivity and encourage formalization of the agricultural labour market.
\end{abstract}

Key words: $\quad$ Stochastic frontier, non-neutral frontier, technical efficiency.

JEL Classification Code: $\quad$ C33, C51, O13, Q12.

\footnotetext{
${ }^{1}$ Correspondence:

Sheikh Selim, Cardiff Business School, Aberconway, Colum Drive, Cardiff University, CF10 3EU, United Kingdom; email: selimsT@cardiff.ac.uk.
} 


\section{Introduction.}

In this paper we examine the correspondence between labour productivity and technical efficiency of rice production in Bangladesh in a stochastic non-neutral production frontier. We conduct this study for a particular hybrid of rice in Bangladesh, namely Aus, for a panel data across 23 major rice producing districts over 1994-1999 period. Our study is mainly motivated by the informal structure of the agricultural labour market, negative output growth of this particular hybrid rice, and overall decline in rice production growth in Bangladesh. We review the stages of agricultural policy reform in Bangladesh and discover that while the major reforms were targeted towards the use of scientific means of cultivation and deregulating the market for material inputs, none of the reforms highlighted the importance of improving labour productivity and formalizing the labour market (e.g. no specific incentive design for the farmers to adopt scientific means of cultivation). We conduct the frontier estimation in order to examine the correspondence between technical inefficiency, labour productivity and interaction of labour productivity with the use of inputs. We find that identifying this correspondence assists one in explaining the persistent decline in rice production.

We follow Huang and Liu (1994)'s modeling approach in order to capture the interaction effect of labour productivity and other inputs in a non-neutral frontier. Typically, a neutral production frontier implicitly assumes that technical efficiency changes are either autonomous or induced by changes in the industry specific characteristics. It therefore assumes that technical efficiency changes are completely independent of changes in input use, or interactions among industry specific characteristics and input use. When considering the determinants of technical efficiency changes, one must recognize that time-varying technical efficiency may also respond to changes in input use, and interaction, or cross effects of inputs and productivity of other inputs. This is the key idea underlying the use of a non-neutral frontier.

In this study the non-neutrality assumption allows us to model interaction effects between labour productivity and other inputs of production. Our hypothesis here is that although high yield seeds and high powered fertilizers are likely to contribute to improved production of rice, the interaction between scientific inputs and low labour productivity depresses technical efficiency gains. Excess supply of labour, more in the form of surplus labour, is generally associated with low labour productivity and low total productivity. Approximately $23 \%, 59 \%$ and $16 \%$ of the 
total agricultural labour force in Bangladesh comprises of self-employed farmers, unpaid family workers and day-laborers ${ }^{2}$. Together they make a large proportion of the agricultural labour market an informal market with little collective bargaining power for wages. Our hypothesis is that the underutilization of productive capacity, or more simply the inefficiency in production that resulted in negative growth rate in production, is mainly due to the interaction of low labour productivity and the use of new technology. We capture this interaction effect by modeling interactions between marginal wage and the factors of production as determinants of technical inefficiency. We find that such interactions significantly affect technical efficiency in hybrid Aus' production. With huge surplus labour in rice production, extended use of scientific inputs such as hybrid seeds and fertilizers depresses the efficiency gains in production. Their use can excel the efficiency gains only if there is an increase in labour productivity.

\section{The Context.}

There are three popular rice hybrids in Bangladesh, Aus, Aman and Boro. Both Aman and Boro are cropped round the year, while Aus is cropped during March to September. During the mid eighties, all three hybrids went through modernization with the introduction of high yield seeds, scientific methods of irrigation, fertilization and harvest. This resulted in an initial phase of growth in rice production, which eventually lasted for a brief period. Baffes and Gautam (1996) argue that the observed growth in aggregate rice production in Bangladesh until the early nineties was mainly because of conversion of rice growing areas from local to modern varieties. We present Baffes and Gautam (1996) estimates of growth rates of these hybrids in figure 1. From the mid to late nineties, aggregate rice production growth rate declined. According to BBS reports, the rice production growth target in the late nineties was $4.23 \%$ and the actual achieved was $0.95 \%$. The projected growth rate of Aman production and Boro production in the late nineties were $3.03 \%$ and $6.07 \%$ and the actual achieved were $0.61 \%$ and $4.41 \%$, respectively. The production growth of Aman actually dropped from its eighties' average 1.64\%, while that of Boro dropped from its eighties' average 7.10\%. For Aus the statistics are worse. The target growth rate in Aus in late nineties was $3.5 \%$ but its production declined by $-3.22 \%$, following a trend of

\footnotetext{
2 All statistics, including the data for our regressions are collected from Yearbook of Agricultural Statistics of Bangladesh, published by Bangladesh Bureau of Statistics (BBS). We verify national level data and the most recent statistics from two other sources, Sustainable Development Network of Bangladesh (SDNBD), and Agricultural Statistical Yearbook of Bangladesh from the Ministry of Agriculture, both of which are available online. The district level data are available from Zila Series Census and Zila statistics of BBS.
} 
declines of $-3.43 \%$ and $-2.89 \%$ in the eighties and early nineties. In figure 2 we present the trend in production of the three rice hybrids during 1980-2002, according to BBS reports.

With the introduction of modern hybrids, more area under cultivation was allocated to Boro production. Boro's cultivation is the least effort-intensive and its growth largely depends on timing of cultivation, land fertility and weather. Given a fixed supply of land, and since there is little choice for diverting Aman's land to other crops because of high soil moisture and poor drainage, this had to be done at the expense of taking away land from Aus production. Some studies find a significant impact of this land reform in the drop in rice production growth rate in Bangladesh. Sharif and Dar (1996), for instance, find that there exists low technical efficiency in the production of modern variety of rice in Bangladesh, and one of the key factors affecting technical inefficiency in the production of particular hybrids is the land reform policy. Mahmud, Rahman and Zohir (1994) also argue along the same lines. None of these studies, however, examine explicitly if labour productivity had a significant impact on technical efficiency.

We conduct the study only on hybrid Aus. This is mainly because (a) its production growth is negative; (b) its cultivation is effort as well as material input-intensive, which is why we hypothesize labour productivity and scientific means of cultivation and their interaction may have a role to play, and (c) a significant proportion of its area under cultivation was given away to Boro production. We combine these facts, i.e. the persistent negative growth rate in Aus production, high emphasis on scientific inputs and modern varieties, the informal structure of labour market that provides little incentive to enhance productivity, and the land reform policy. We hypothesize that the decline in Aus production is mainly due to a combination of low marginal wage paid to farmers and depression of efficiency gains due to interaction of low labour productivity and the use of inputs (such as land, improved fertilizers and seeds). We examine the technical inefficiency effects in district level Aus production and attempt to explain the failure to achieve target growth rate in production. In order to identify areas for policy reform, we look at the history of agricultural policy reform in Bangladesh and shortlist what has been done and what has not been done. We have collected this important information on policy reforms combining various Five-Year Plan Documents of the Ministry of Finance and Planning of the Government of Bangladesh. We present a summary of the key reforms in three main phases in chart 1. During the first phase of reforms, mainly due to quantity rationing, demographic pressure failed to induce agricultural growth. This encouraged the government to adopt a new input technology package including scientific means of irrigation, fertilizers, pest control and high yield seeds. During the 
late eighties, the government undertook output price support policy and at tandem withdrew food subsidies in the urban rationing system and agricultural input subsidies. Understandably, the main reason behind this reform was that the rate of increase in prices of imported fertilizer and improved seeds was persistently higher than the rate of increase in rice price. Farmers from smaller districts were subject to high intensity and high price elasticity of demand for fertilizer and improved seeds. This was due to management costs involved in procuring these from divisional headquarters where these inputs were primarily supplied and stocked.

\section{Chart 1: Key agricultural policy reforms in Bangladesh 1977-1994.}

\begin{tabular}{|l|l|l|l|}
\hline Period & \multicolumn{1}{|c|}{ Policy } & \multicolumn{1}{|c|}{ Purpose } & \multicolumn{1}{|c|}{ Observed consequence } \\
\hline $1977-1983$ & $\begin{array}{l}\bullet \text { Input subsidy, (no wage subsidy); } \\
\bullet \text { Market quantity rationing. }\end{array}$ & $\begin{array}{l}\text { Centralized support to } \\
\text { agriculture and self } \\
\text { sufficiency in food. }\end{array}$ & $\begin{array}{l}\text { Agricultural growth, but low } \\
\text { technology growth. }\end{array}$ \\
\hline $1983-1988$ & $\begin{array}{l}\bullet \text { Input technology package; } \\
\bullet \text { Withdrawal of direct input subsidy; } \\
\text { Output price support. }\end{array}$ & $\begin{array}{l}\text { High growth in } \\
\text { production, and price } \\
\text { support to meet new } \\
\text { higher input costs. }\end{array}$ & $\begin{array}{l}\text { Low output growth, } \\
\text { slow rate of technology } \\
\text { adoption. }\end{array}$ \\
\hline $1989-1994$ & $\begin{array}{l}\bullet \text { Deregulation of input supply; } \\
\bullet \text { Land reforms; }\end{array}$ & $\begin{array}{l}\text { High growth in } \\
\text { production, high } \\
\text { competition and higher } \\
\text { efficiency in land use. }\end{array}$ & $\begin{array}{l}\text { Decline in Aus production, } \\
\text { less than projected growth in } \\
\text { production of other hybrids. }\end{array}$ \\
\hline
\end{tabular}

It was recognized that in a state of overwhelming dependence on weather, when prices fluctuate with output, only price support policy to stimulate output is often ineffective. The concern of overwhelming dependence on land fertility propelled land reform policies. In addition, in order to improve the distributional channels, the government decided to move towards deregulation. The agricultural reforms in the nineties phase can be characterized as ones of regulatory reforms of input supply side towards deregulation and liberalization of input supply chains, crop diversification, and extended rice research and widening genetic base of rice.

The phases of reforms suggest that the government moved gradually towards a more scientific package of material inputs, towards allocating more land to weather dependent hybrids, and towards a more liberalized agricultural input market; but during the process the government did very little in providing incentives to farmers to adopt the new technology. The issue is not one of 
providing direct subsidies or output price support to farmers, since these are essentially associated with disincentive effects of different magnitudes. There were no reforms particularly targeted at formalizing the agricultural labour market (e.g. farm income registration, or introducing farminvestment subsidy). Since surplus labour earns zero marginal wage and thus adds little to the marginal product, without proper training and awareness, providing this labour force with new technology, hybrid seeds and new capital will in general depress agricultural productivity, or efficiency in production. To see this more formally, consider a simple correspondence between technical efficiency and labour productivity. If all workers are paid their marginal product (and no worker is paid zero wage), they essentially induce more effort in order to increase their marginal product. Higher labour productivity reduces technical inefficiency since it adds value to the marginal productivity of other inputs. In the current context it is interesting to examine the variation in this effect due to interactions of productivity with the inputs. If labour productivity is low, and if the labour market is predominantly informal, adding more fertilizer or seeds (or working days) to cultivation will depress the marginal effect of labour productivity on efficiency, since a predominantly informal labour force is less likely to exert more effort in order to use scientific inputs efficiently. We test this hypothesis in this paper. If our hypothesis is supported by data, it would imply that policy reforms in future should put emphasis on labour market reforms rather than flat subsidies.

\section{The Model.}

We follow the standard stochastic frontier production function approach, proposed independently by Aigner, Lovell and Schmidt (1977) and Meeusen and van den Broeck (1977), which postulates the existence of technical inefficiencies of production of agents involved in producing a particular output. This study therefore complements important works in this area, such as Forsund, Lovell and Schmidt (1980), Bauer (1990), Cornwell, Schmidt and Sickles (1990), Battese and Coelli (1988, 1992 \& 1995), Sharma and Leung (1998) and Jha and Rhodes (1999). In addition, we consider time variant technical inefficiency and non-neutral efficiency estimation, as in Karagiannis and Tzouvelekas (2005)'s study of sheep farming in Greece. In particular, we work with a standard stochastic frontier model:

$$
\ln q_{i t}=f(\ln x)+v_{i t}-u_{i t} ; \quad i=1, \ldots \ldots, N ; t=1, \ldots \ldots, T
$$


where $q_{i t}$ denotes output of district $i$ in year $t$, and $x$ represents an input vector. The term $v_{i t}$ is a symmetric and normally distributed random error, which represents those factors that cannot be controlled by farmers, measurement errors in the dependent variable, and omitted explanatory variables. We assume, as is standard, that $v_{i t}$ have normal distribution with zero mean and standard deviation $\sigma_{v} \cdot v_{i t}$ are independent of $u_{i t}$, which are non-negative random variables that account for technical inefficiency in production. These are assumed to be independently and identically distributed and truncations (at zero) of the distribution $\left|N\left(u_{i t}, \sigma_{u}^{2}\right)\right|$. This distribution allows for a wider range of distributional shapes including nonzero modes ${ }^{3}$.

Following Battese and Coelli (1995), we define $\sigma_{s}^{2} \equiv \sigma_{v}^{2}+\sigma_{u}^{2}$ and compute $\gamma \equiv \frac{\sigma_{U}^{2}}{\left(\sigma_{U}^{2}+\sigma_{V}^{2}\right)}$, where $\gamma \in[0,1]$. If $\gamma$ is significantly different from zero, it can be used to determine the source of variation in production and the extent of the impact of technical inefficiency effects as compared to random shocks or stochastic effects ${ }^{4}$. We use a translog production frontier. This specification does not impose assumptions about constant elasticity of production nor elasticity of substitution between inputs, allowing the data to indicate the actual curvature of the function. We use the following specification:

$\ln q_{i t}=b_{0}+\sum_{j} b_{j} \ln x_{j i t}+\sum_{j} b_{j j}\left(\ln x_{j i t}\right)^{2}+\sum_{j} \sum_{k} b_{j k} \ln x_{j i t} \cdot \ln x_{k i t}+v_{i t}-u_{i t}$

Following Huang and Liu (1994), we further assume that the technical inefficiency is a function of district specific characteristics, use of inputs, and interactions between characteristics and inputs. In particular, we assume that inefficiency depends on two sets of variables, $z_{i t}$ and $z_{i t}{ }^{*}$. The first represents some district-specific characteristics which may influence the district's

\footnotetext{
${ }^{3}$ There are other possible distributions of $u_{i t}$ and there are no a priori reasons for choosing one distributional form over the others. For instance, modelling with a half-normal distribution that has a mode at zero in this case would impose an assumption that a high proportion of the districts being examined are perfectly efficient. This is the same imposition if one considers an exponential distribution.

${ }^{4}$ A low value of $\gamma$ would indicate that $\sigma_{u}^{2}$ is small and $\sigma_{v}^{2}$ is large, so stochastic or random effects such as weather variations cause less than frontier level of output, and variations from frontier level of output (given the set of inputs) are not due to any technical inefficiency effects. A high value of $\gamma$ would thus indicate that most of the variation from frontier level of output is due to technical inefficiency effects rather than random variations.
} 
efficiency. The second represents the inputs in production, and interactions between $z_{i t}$ and the input variables in the stochastic frontier. Simultaneously with the stochastic frontier we estimate:

$u_{i t}=z_{i t} \delta+z_{i t}^{*} \delta^{*}+A_{t}+w_{i t}$

where $w_{i t}$ are unobservable random variables assumed to be independently distributed, obtained by truncation of the normal distribution with mean zero and variance, $\sigma_{w}^{2}$, such that $u_{i t}$ is nonnegative, and $A_{t}=\sum_{t=2}^{T} \delta_{t} D_{t}$ where $D_{t}$ are time dummies. The measure of technical efficiency is $T E_{i t}=e^{-u_{i t}}$. The technical efficiency measure is thus constrained to be between zero and one. District $i$ is operating at the technically efficient level at any time $t$ if its output in on the frontier, since technical efficiency of the $i$ th district at any time $t$ is a relative measure of its output as a proportion of the corresponding frontier output ${ }^{5}$. We use Maximum Likelihood estimation. Thus, our pooled estimation is based on a joint density function for the split error term $v_{i t}-u_{i t}$. With district level data we model the frontier with four inputs. The elasticity of output at any time $t$ with respect to the $j-t h$ input, $\mu_{j t}$ for $j=1,2,3,4$; evaluated at the mean values of relevant data points can be derived as:

$\mu_{j t}=b_{j}+2 b_{j j} \ln x_{j t}+\sum_{k \neq j} b_{j k} \ln x_{k t}$

Given our estimation of a panel data, neglecting heteroscedasticity would result in biased estimates of both the $b \mathrm{~s}$ and technical efficiency, especially when factors affecting technical inefficiency and the inputs in production are highly correlated. Notice that we have assumed a constant variance of $u_{i t}$. If the variance depends on district specific characteristics and this intuition is ignored in the estimation process, the resulting estimation would lead to downward (upward) biased estimates of technical efficiency for relatively small (large) districts. While choosing the district, we make an attempt to get around this problem. We choose the 23 rice producing districts that have nearly similar cropping intensity, where cropping intensity is defined as (total cropped area/net sown area)*100. We also conduct a formal heteroscedasticity test. We 
assume that since the districts have similar cropping intensity, the heteroscedasticity may be mainly due to other district specific characteristics, namely, meteorological condition (e.g. rain intensity), labour productivity and use of bullock days. We assume, following Karagiannis and Tzouvelekas (2005), that the variance function is exponential, which takes the form:

$\ln \sigma_{u i t}^{2}=\xi_{0}+\xi_{1} z_{6 i t}+\xi_{2} z_{8 i t}+\xi_{3} z_{13 i t}$

This extends our set of robustness tests. In summary, we perform the following tests. We test that the technical inefficiency effects are absent, i.e. $\gamma=\delta_{0}=\delta_{1}=\ldots \ldots . .=\delta_{j}=0$, technical inefficiency effects are non-stochastic, i.e. $\gamma=0$, and hypothesized factors do not influence the technical inefficiencies, $\delta_{1}=\ldots \ldots . .=\delta_{j}=0$. The constant returns to scale assumption in the translog stochastic production frontier (2) imposes a number of linear restrictions on the parameters, which are:

$$
\begin{aligned}
& \sum_{j=1}^{4} b_{j}=1 \\
& 2 b_{11}+b_{12}+b_{13}+b_{14}=0 \\
& b_{12}+2 b_{22}+b_{23}+b_{24}=0 \\
& b_{13}+b_{23}+2 b_{33}+b_{34}=0 \\
& b_{14}+b_{24}+b_{34}+2 b_{44}=0
\end{aligned}
$$

We test $b_{j j}=b_{j k}=\delta^{*}=0 ; j \neq k$, acceptance of which says that the translog non-neutral frontier can be rejected in favor of a neutral Cobb-Douglas production frontier. We also test the assumption of interactions of district specific characteristics and use of inputs, i.e. we test whether these interactions are jointly significant in determining technical inefficiency. Finally, we test for heteroscedasticity, i.e. we perform a test on the null hypothesis of homoscedasticity, $\xi_{1}=\xi_{2}=\xi_{3}=0$. We test these null hypotheses using the generalized likelihood-ratio statistic, where the statistic follows approximately a chi-square distribution with degrees of freedom equal to the number of restrictions in the null hypothesis, provided the null hypothesis is true, and a mixed chi-square distribution when the null hypothesis involves $\gamma=0$.

\footnotetext{
${ }^{5}$ Given the current context, district level technical efficiency may be viewed as the utilization of capacity in an industry.
} 


\section{Data and Estimation.}

All data are from Yearbook of Agricultural Statistics of Bangladesh, a publication of Bangladesh Bureau of Statistics (BBS) that presents primary information on district and national level agricultural production. The other two secondary sources of agricultural data are the Sustainable Development Network of Bangladesh (SDNBD) and Agricultural Statistical Yearbook of Bangladesh from the Ministry of Agriculture, both of which are available online, and use our original data source. We collect data for 23 major rice-producing districts over 1994-1999 period for hybrid Aus. The districts are selected with similar cropping intensity, from all 6 divisions of Bangladesh (and from all zones) including the divisional headquarters. Districts were divided into four cropping zones (south, north, east and west) and two cropping zones (south and north) and efficiency model was estimated for both using 3 zone dummy variables and 1 zone dummy variable, respectively. The latter was selected on the basis of likelihood ratio test ${ }^{6}$. Six divisional headquarters, namely, Dhaka, Sylhet, Chittagong, Barisal, Rajshahi and Khulna were assigned a value 1 for the head dummy. These headquarters are demand centers and the main divisional market.

The output data of hybrid Aus is taken as aggregate district production of Aus rice in tonnes (or metric ton). The inputs are land area (in hectares) under cultivation of Aus, improved Aus seeds (in tonne), chemical fertilizer used in Aus production (in tonne), and agricultural labour measured in full-time annual working days of total labour force during cropping season of Aus. Since bullocks and tractors are used in cultivation in the event of low rainfall during cropping season, bullock days is used in the technical efficiency model to act as an inverse proxy for rainfall ${ }^{7}$. As determinants of technical inefficiency, some district specific characteristics are considered. The rain intensity variable is created taking a ratio of rainfall in millimeters to humidity in percentage

\footnotetext{
${ }^{6}$ On an average, south zone districts with a land altitude of less than or equal to 10 meters from the sea level are expected to have more fertility of land. This is because weather conditions in these regions allow for more tropical monsoon rain that drenches the land and rivers creating huge deposits of silt in the land. The zone difference of districts is due to different altitudes of land from sea level (and not only on geographical positioning). Since the Bay of Bengal is to the south of Bangladesh, most districts to the south are approximately within 10 meters of land altitude from the Bay of Bengal. Districts with cropping land within 10 meters above the sea level are designated south zone districts (having low land and very low land), and have been assigned a value 1 for the zone dummy variable. Districts with medium highlands, hills and highlands (land altitude of over 10 meters from sea level) are designated north zone districts.

${ }^{7}$ We do not find any district level data on tractors, irrigation machinery and pesticides for Bangladesh. We also find very less variation in cropping season average rainfall across districts and over time (although there is reasonable variation in the rain intensity). We therefore include bullock days as an inverse proxy for rainfall.
} 
to account for cropping season rain intensity in millimeters for $1 \%$ humidity. We follow Nwaokoro (2006) and hypothesize that farmers' real (and not nominal) marginal wage has a direct correspondence with their productivity. In addition, keeping in mind the informal structure of the labour market in Bangladesh agriculture, we assume that the wage function is linear such that average real wage is equal to their marginal real wage. We therefore use Aus farmers' average daily real wage as a proxy for labour productivity. The wage data we use is an average wage rate (in real BD taka) for cropping seasons of Aus rice, averaging over per day without meal male and female wage rates.

Inefficiency is modeled to depend on inputs, and four more arguments which are interactions between wage and inputs. These are $\ln ($ area $) *($ wage $), \quad \ln ($ seed $) *($ wage $)$, $\ln ($ fertilizer $) *($ wage $)$, and $\ln ($ labour $) *$ wage. The inputs, and these four in the inefficiency estimation represent the non-neutrality, and enables us to examine the cross effects of labour productivity and input use. The data and variable tables are in appendix, Table 1. The Maximum Likelihood estimation results are presented in appendix table 2. We use likelihood ratio test to choose the translog production frontier over a Cobb Douglas specification. Also, the non-neutral frontier is accepted over the neutral one on the basis of likelihood ratio test.

\section{Tests of Hypotheses.}

Most of the estimated parameters are statistically significant (at 5\% and 10\% levels). Generalized likelihood-ratio tests of various null hypotheses involving restrictions on the variance parameter, $\gamma, b \mathrm{~s}$ in the stochastic production frontier, $\delta \mathrm{s}$ in the technical inefficiency model, choice of model specification, aggregate returns to scale, and heteroscedasticity, are presented in appendix table 3. Critical value for $5 \%$ level of significance for the first and second null hypotheses involving $\gamma=0$, are collected from table 1 of Kodde \& Palm (1986, p.1246). This is because the estimated test statistic for these restrictions, if the restriction holds true, follows a mixed chisquare distribution. The critical values for the other tests are taken from standard chi-square tables.

From table 3, the first null hypothesis, which specifies that the inefficiency effects are absent from the model, is strongly rejected at $5 \%$ level. The second null hypothesis, that the inefficiency effects are not stochastic, is also strongly rejected at 5\% level. The third null hypothesis, which 
states that inefficiency effects are not a linear function of the determinants considered, is also strongly rejected at $5 \%$ level. The null hypothesis of constant returns to scale for the production technology is accepted by the data. The fifth null hypothesis, stating that the model for hybrid Aus production can be estimated using a Cobb-Douglas neutral frontier specification, is strongly rejected, which justifies the choice of translog non-neutral frontier. The null hypothesis that the interaction effects of district specific characteristics and use of inputs on technical inefficiency are insignificant is also rejected at 5\% level. This test confirms our choice of the specification. We accept homoscedasticity over heteroscedasticitiy as we fail to reject the null hypothesis of constant variance of $u_{i t}$.

\section{Computations and Interpretations.}

We present a frequency distribution of estimated technical efficiency ratings in our sample in table 4. The estimates of technical efficiency indicate the consistency and reliability of our model specification. Technical efficiency estimate range from 0.29 to 0.99 . Estimated mean technical efficiency for 1994-1999 is $79.7 \%$, implying that output could have increased substantially if technical inefficiency was eliminated.

We compute the marginal effect of inputs and wage on technical inefficiency, and the cross effects of inputs on the marginal effect of wage (at mean value), and report these in table 5. The important thing to consider from this table is the sign of these effects. Notice that given our specification of the technical inefficiency, the marginal effect of wage increase (i.e. labour productivity) on technical inefficiency is:

$\frac{\partial u_{i t}}{\partial w_{i t}}=\delta_{8}+\delta_{9} \ln ($ area $)+\delta_{10} \ln ($ seed $)+\delta_{11} \ln ($ fertilizer $)+\delta_{12} \ln ($ labour $)$

The cross effects are derived by differentiating (7) with respect to individual inputs. The signs of the estimates of $\delta_{9}, \delta_{10}, \delta_{11}, \delta_{12}$ therefore represent the directions of cross effects. Notice from table 5 that increasing land area for cultivation or wages induce efficiency gain (negative marginal effect on technical inefficiency), a finding which is consistent with both Baffes and Gautam (1996) and Sharif and Dar (1996). For other inputs, higher use induces efficiency loss. This result is consistent with the intuition that with low labour productivity and existence of 
surplus labour, introducing more seeds, fertilizer or labour will create a congestion effect that will reduce efficiency of the industry. Untrained workforce will not cope with the scientific materials, and more working days will reduce labour productivity further, both of which are attributable to further inefficiency in production. The cross effects are representative of the marginal change in wage effect (the labour-productivity induced efficiency gain) for additional use of inputs. This effect is positive for land, seed and fertilizer but negative for labour. The positive cross effects suggest that if labour productivity is improved, increased use of inputs such as land, seed and fertilizer will contribute to the rate of labour-productivity induced marginal efficiency gain. Thus any further land reform (which allocates more land to Aus production) or input subsidies will achieve their goals only if labour productivity is improved.

The estimated coefficient for zone dummy variable is -0.02 and it is statistically significant at 5\% level, implying that south zone districts with more fertile land tend to be more (and significantly) technically efficient in producing Aus. Head quarter dummy variable is statistically significant and divisional headquarters possess a higher mean inefficiency, implying that favored demand centers did not experience higher efficiency than relatively remote areas. A high and statistically significant value of gamma for the model indicates that most of the deviation of output from frontier level is due to technical inefficiency rather than from "random shocks" like weather variations.

The estimates of output elasticity evaluated at means of relevant data points and returns to scale are presented in appendix table 6. The output elasticity of labour is negative (and low) for all years and insignificant for two years. This suggests that the production technology is a wellbehaved one for inputs area, seeds and fertilizer. This also confirms our key hypothesis of low labour productivity which is consistent with the surplus labour evidence. Among the estimated elasticity, elasticity of output with respect to area is near one and is statistically significant for all years. Elasticity of output with respect to fertilizer and elasticity of output with respect to seeds are also significantly positive. Production tends to vary very less for variation in seeds or labor. The returns to scale is near one for all years of our sample. These results strongly suggest that agricultural inputs have substitutability in production, and therefore possess significant interaction effects.

\section{Concluding Remarks.}


We estimate a model for technical inefficiency effects in a stochastic production frontier for panel data of Aus rice production across 23 major districts of Bangladesh over 6 years. We assume a translog production function specification and non-neutrality in efficiency distribution. The results indicate that our specification for the technical inefficiency effects is a significant component in explaining the decline in Aus productivity growth in Bangladesh, and that the key reform agenda is one that provides incentives for increasing labour productivity. We also examine output elasticity with respect to different inputs, and degree of homogeneity of production technology.

We find that due to low marginal productivity of labour, extended use of new technology depresses the efficiency gains in production. The low marginal productivity of labour is primarily due to predominantly informal labour market and the unwillingness to learn new technology. We argue that agricultural reforms towards higher productivity growth should address the incentive schemes for labour. Rather than subsidizing input prices or supporting output prices which has inherent disincentives to learn new technology, reforms should provide incentives for training and formalizing the rural labour market. This phenomenon, i.e. the conflict between traditional practices and new technology practice is not new in developing countries. We show the correspondence between this conflict and utilization of existing capacity, and highlight the importance of resolving this conflict. We conclude that future agricultural policy reforms in Bangladesh should therefore put more emphasis on enhancing labour productivity and formalizing the agricultural labour market.

The issue of high labour productivity induced efficiency gains and productivity growth is one of a vibrant debate in development theory. There exists a strong view, led mainly by Adam Smith, focusing on market induced regionally concentrated scale economies and gains from specialization. The other view, known as the Boserupian view, connects decreasing labour productivity with long lasting output growth induced primarily by demographic pressures. This view fits the current agricultural context of Bangladesh. Without investing in skills of agricultural labour, or without formalizing the labour market, the use of scientific inputs results in a slow technical change. Since land fertility (and area) is not constant, scientific inputs are subject to underutilization, or misuse. On the other hand, low marginal wage paid to farmers and familyheads who work with unpaid members provides little incentives to induce more effort. Without government's direct intervention, wage income thus can only be increased by registering income as farm income rather than farmer income. A wage subsidy fails to serve the purpose of 
increasing labour productivity since it is associated with misreporting of working hours. An incentive to increase registered farm level income may induce farm-heads to design payment schemes to all farmers including family members. In Bangladesh, approximately $16 \%$ of the family unpaid workers are school dropout children of farmers. A labour productivity enhancing policy thus should be supported by awareness programs and incentives for arranging alternative arrangements for these children. Such arrangement may include schooling, but more importantly, they may include formal agricultural training leading to accreditations.

\section{Acknowledgements.}

The author acknowledges Cardiff Business School's seed-corn fund for this particular project.

\section{References.}

Aigner, D. J., Lovell, C. K. \& Schmidt, P. (1977). "Formulation and Estimation of Stochastic Frontier Production Function Models", Journal of Econometrics, Vol. 6, 21-37.

Baffes, J. \& Gautam, M. (1996). “Is Growth in Bangladesh's Rice Production Sustainable?”, Policy Research Working Paper 1666, The World Bank.

Battese, G. E. \& Coelli, T. J. (1988). "Prediction of Firm-level Technical Efficiencies with a Generalized Frontier Production Functions and Panel Data", Journal of Econometrics, Vol. 38(3), 387-399.

(1992). "Frontier Production Functions, Technical Efficiency and Panel Data with Application to Paddy Farmers in India”, Journal of Productivity Analysis, Vol. 3, 153-169.

(1995). “A Model for Technical inefficiency Effects in a Stochastic Frontier Production Function for Panel Data", Empirical Economics, Vol. 20, 325-332.

Bauer, P. W. (1990). "Recent Developments in the Econometric Estimation of Frontiers", Journal of Econometrics, Vol. 46, 39-56.

Cornwell, C. P., Schmidt, P. \& Sickles, R. (1990). "Production Frontiers with Cross-sectional and Time-series Variation in Efficiency", Journal of Econometrics, Vol. 46, 185-200.

Forsund, F. R., Lovell, C. K. \& Schmidt, P. (1980). “A Survey of Frontier Production Functions and Their Relationship to Efficiency Measurement", Journal of Econometrics, Vol. 13, 5-25.

Huang, C. J. \& Liu, J. T. (1994). "Estimation of a Non-neutral Stochastic Frontier Production Function”, Journal of Productivity Analysis, Vol. 5, 171-180. 
Jha, R. \& Rhodes, M. J. (1999). "Some Imperatives of the Green Revolution: Technical Efficiency and Ownership of Inputs in Indian Agriculture", Agricultural and Resource Economics Review, Vol. 25, 57-64.

Karagiannis, G. \& Tzouvelekas, V. (2005). "Explaining Output Growth with a Heteroscedastic Non-neutral Production Frontier: The Case of Sheep Farms in Greece", European Review of Agricultural Economics, Vol. 32(1), 51-74.

Kodde, D. A. \& Palm, F. C. (1986). "Wald Criteria for Jointly Testing Equality and Inequality Restrictions", Econometrica, Vol. 54(5), 1243-1248.

Mahmud, W., Rahman, S. H. \& Zohir, S. (1994). Agricultural Growth Through Crop Diversification in Bangladesh, International Food Policy Research Institute, Working Paper No. 7.

Meeusen, W. \& van den Broeck, J. (1977). "Efficiency Estimation from Cobb-Douglas Production Functions with Composite Error", International Economics Review, Vol. 18(2), 435444.

Nwaokoro, A. N. (2006). "Real Wage Rate And Productivity Relationship In The Declining U.S. Steel Industry”, International Business \& Economics Research Journal, Vol. 5, 87-94.

Sharif, N. R. \& Dar, A. A. (1996). “An Empirical Study of the Patterns and Sources of Technical Inefficiency in Traditional and HYV Rice Cultivation in Bangladesh", Journal of Development Studies, Vol. 32, 612-629.

Sharma, R. K. \& Leung, P. (1998). "Technical Efficiency of the Longline Fishery in Hawaii: An Application of a Stochastic Production Function", Marine Resource Economics, Vol. 8, 259-274. 
Table 2: Translog non-neutral stochastic frontier estimation.

\begin{tabular}{|c|c|c|c|c|}
\hline & Variable/Intercept & Parameter & Estimate & t-ratio \\
\hline $\begin{array}{l}\text { Production } \\
\text { Frontier }\end{array}$ & $\begin{array}{l}\text { Intercept } \\
\ln (\text { area }) \\
\ln (\text { seed }) \\
\ln (\text { fertilizer }) \\
\ln (\text { labour }) \\
\ln (\text { area }) * \ln (\text { area }) \\
\ln (\text { seed }) * \ln (\text { seed }) \\
\ln (\text { fertilizer }) * \ln (\text { fertilizer }) \\
\ln (\text { labour }) * \ln (\text { labour }) \\
\ln (\text { area }) * \ln (\text { seed }) \\
\ln (\text { area }) * \ln (\text { fertilizer }) \\
\ln (\text { area }) * \ln (\text { labour }) \\
\ln (\text { seed }) * \ln (\text { fertilizer }) \\
\ln (\text { seed }) * \ln (\text { labour }) \\
\ln (\text { fertilizer }) * \ln (\text { labour })\end{array}$ & $\begin{array}{l}b_{\text {n }} \\
b_{1} \\
b_{2} \\
b_{3} \\
b_{4} \\
b_{11} \\
b_{22} \\
b_{33} \\
b_{44} \\
b_{12} \\
b_{13} \\
b_{14} \\
b_{23} \\
b_{24} \\
b_{34}\end{array}$ & $\begin{array}{c}0.269 \\
2.071 \\
0.304 \\
0.062 \\
0.042 \\
-0.081 \\
-0.0062 \\
0.0054 \\
-0.0092 \\
0.127 \\
-0.051 \\
0.149 \\
0.039 \\
-0.027 \\
-0.0071\end{array}$ & $\begin{array}{c}0.79 \\
1.97 * \\
2.17 * * \\
2.47 * * \\
1.36 \\
-2.23 * * \\
-1.95 * \\
2.04 * \\
-3.27 * * \\
2.21 * * \\
-3.23 * * \\
3.06 * * \\
4.69 * * \\
-0.61 \\
-2.42 * *\end{array}$ \\
\hline $\begin{array}{l}\text { Technical } \\
\text { Inefficiency } \\
\text { Estimation }\end{array}$ & $\begin{array}{l}\text { Intercept } \\
\ln \text { (area) } \\
\ln (\text { seed) } \\
\ln (\text { fertilizer) } \\
\ln (\text { labour) } \\
\text { Head Quarter Dummy } \\
\text { Rain Intensity } \\
\text { Zone Dummy } \\
\text { Wage } \\
\text { Wage*ln(area) } \\
\text { Wage*ln(seed) } \\
\text { Wage*ln(fertilizer) } \\
\text { Wage*ln(labour) } \\
\text { Bullock } \\
\text { Time Dummies }\end{array}$ & $\begin{array}{l}\delta_{n} \\
\delta_{1} \\
\delta_{2} \\
\delta_{3} \\
\delta_{4} \\
\delta_{5} \\
\delta_{6} \\
\delta_{7} \\
\delta_{8} \\
\delta_{9} \\
\delta_{10} \\
\delta_{11} \\
\delta_{12} \\
\delta_{13} \\
\delta_{14} \\
\delta_{15} \\
\delta_{16} \\
\delta_{17} \\
\delta_{18}\end{array}$ & $\begin{array}{c}0.015 \\
0.013 \\
0.91 \\
-0.002 \\
0.0002 \\
-0.284 \\
0.901 \\
-0.466 \\
0.914 \\
0.122\end{array}$ & $\begin{array}{c}0.14 \\
-1.41 \\
-2.62^{* *} \\
-2.33^{* *} \\
2.02^{*} \\
2.19^{* *} \\
0.42 \\
-2.91^{* *} \\
1.98^{*} \\
2.47^{* *} \\
3.42^{* *} \\
2.03^{*} \\
2.01^{*} \\
0.35 \\
-0.81 \\
0.25 \\
-2.54^{* *} \\
1.02 \\
1.55\end{array}$ \\
\hline & $\begin{array}{l}\gamma \\
\text { Sigma sqaured } \\
\text { log likelihood function }\end{array}$ & & $\begin{array}{c}0.91 \\
0.422 \\
32.12\end{array}$ & $\begin{array}{c}18.26 * * \\
8.99 * *\end{array}$ \\
\hline
\end{tabular}

Notes: *Statistically Significant at $10 \%$ level. **Statistically Significant at $5 \%$ level. 
Table 3: $\quad$ Likelihood ratio test summary.

\begin{tabular}{ccccc}
\hline Null hypothesis & $\ln ($ likelihood) & $\begin{array}{l}\text { Critical value for } \\
5 \% \text { significance }\end{array}$ & $\begin{array}{l}\text { Test } \\
\text { Statistic }\end{array}$ & Decision \\
\hline$\gamma=\delta_{0}=\delta_{1}=\ldots \ldots . .=\delta_{18}=0$ & -16.21 & 19.045 & 96.66 & Reject Null \\
$\gamma=0$ & -15.08 & 5.138 & 94.4 & Reject Null \\
$\delta_{1}=\ldots \ldots . .=\delta_{18}=0$ & -4.836 & 28.869 & 73.91 & Reject Null \\
$\sum \mu_{j}=1$ & 34.77 & 11.071 & 5.3 & Accept Null \\
$b_{j j}=b_{j k}=\delta^{*}=0 ; j \neq k$ & 12.413 & 30.144 & 52.44 & Reject Null \\
$\delta_{9}=\delta_{10}=\delta_{11}=\delta_{12}=0$ & 11.26 & 9.488 & 41.88 & Reject Null \\
$\xi_{1}=\xi_{2}=\xi_{3}=0$ & 34.11 & 7.815 & 3.82 & Accept Null \\
\hline
\end{tabular}

Table 4: Frequency distribution of technical efficiency ratings.

\begin{tabular}{ccccccc}
\hline Efficiency $(\%)$ & 1994 & 1995 & 1996 & 1997 & 1998 & 1999 \\
\hline$<40$ & 1 & 0 & 0 & 1 & 0 & 0 \\
$40-50$ & 0 & 0 & 0 & 0 & 0 & 0 \\
$50-60$ & 2 & 4 & 2 & 2 & 3 & 2 \\
$60-70$ & 5 & 4 & 4 & 4 & 4 & 5 \\
$70-80$ & 3 & 3 & 2 & 3 & 3 & 2 \\
$80-90$ & 5 & 4 & 2 & 3 & 4 & 4 \\
$90-100$ & 7 & 8 & 13 & 10 & 9 & 10 \\
\hline Mean $(S D)$ & $76.8(0.20)$ & $78.1(0.15)$ & $84.2(0.14)$ & $79.1(0.16)$ & $80(0.14)$ & $80.2(0.15)$ \\
Max & 99.4 & 99.1 & 99.2 & 97.5 & 98.0 & 98.1 \\
Min & 29.2 & 53.2 & 54.2 & 35.9 & 55.1 & 53.2 \\
\hline
\end{tabular}


Table 5: Technical inefficiency effects of wage and inputs.

\begin{tabular}{|c|c|c|c|c|c|c|c|}
\hline & & 1994 & 1995 & 1996 & 1997 & 1998 & 1999 \\
\hline \multirow{5}{*}{ 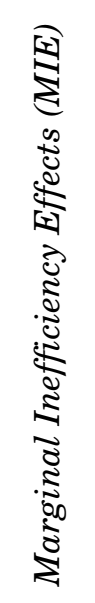 } & $M I E_{\text {Area }}$ & $\begin{array}{c}-0.000054 \\
(-2.71)^{* *}\end{array}$ & $\begin{array}{c}-0.000046 \\
(-0.155)\end{array}$ & $\begin{array}{c}-0.000037 \\
(-1.99)^{*}\end{array}$ & $\begin{array}{c}-0.000032 \\
(-2.03)^{*}\end{array}$ & $\begin{array}{c}-0.000027 \\
(-2.05)^{*}\end{array}$ & $\begin{array}{c}-0.000023 \\
(-0.022)\end{array}$ \\
\hline & $M I E_{\text {Seed }}$ & $\begin{array}{c}0.021 \\
(0.101)\end{array}$ & $\begin{array}{c}0.023 \\
(2.87)^{* *}\end{array}$ & $\begin{array}{c}0.031 \\
(3.33)^{* *}\end{array}$ & $\begin{array}{c}0.031 \\
(3.12)^{* *}\end{array}$ & $\begin{array}{l}0.037 \\
(1.09)\end{array}$ & $\begin{array}{c}0.033 \\
(3.01)^{* *}\end{array}$ \\
\hline & $M I E_{\text {Fertlizer }}$ & $\begin{array}{c}0.0015 \\
(2.82)^{* *}\end{array}$ & $\begin{array}{c}0.0027 \\
(2.57)^{* *}\end{array}$ & $\begin{array}{c}0.0031 \\
(2.91)^{* *}\end{array}$ & $\begin{array}{l}0.0021 \\
(1.91)^{*}\end{array}$ & $\begin{array}{l}0.0026 \\
(2.02)^{*}\end{array}$ & $\begin{array}{c}0.0024 \\
(1.03)\end{array}$ \\
\hline & $M I E_{\text {Labour }}$ & $\begin{array}{l}0.0024 \\
(1.99)^{*}\end{array}$ & $\begin{array}{l}0.0022 \\
(2.05)^{*}\end{array}$ & $\begin{array}{c}0.0022 \\
(0.98)\end{array}$ & $\begin{array}{c}0.0022 \\
(2.99)^{* *}\end{array}$ & $\begin{array}{l}0.0021 \\
(1.94)^{*}\end{array}$ & $\begin{array}{c}0.0020 \\
(1.02)\end{array}$ \\
\hline & $M I E_{\text {Wage }}$ & $\begin{array}{c}-15.09 \\
(-3.03)^{* *}\end{array}$ & $\begin{array}{c}-14.65 \\
(-4.77)^{* *}\end{array}$ & $\begin{array}{l}-14.60 \\
(-2.08)^{*}\end{array}$ & $\begin{array}{l}-15.01 \\
(-1.52)\end{array}$ & $\begin{array}{l}-14.85 \\
(-2.09)^{*}\end{array}$ & $\begin{array}{c}-14.94 \\
(-3.001)^{* *}\end{array}$ \\
\hline \multirow{4}{*}{ 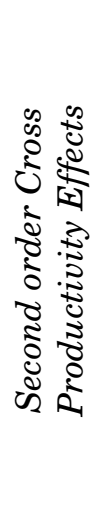 } & $\frac{\partial}{\partial \text { Area }}\left(M I E_{\text {Wage }}\right)$ & 0.000002 & 0.000002 & 0.000002 & 0.000003 & 0.000002 & 0.000002 \\
\hline & $\frac{\partial}{\partial \text { Seed }}\left(M I E_{\text {Wage }}\right)$ & 0.00061 & 0.00060 & 0.00071 & 0.00066 & 0.00075 & 0.00064 \\
\hline & $\frac{\partial}{\partial \text { Fertilizer }}\left(M I E_{\text {Wage }}\right)$ & 0.000042 & 0.000069 & 0.000070 & 0.000045 & 0.000052 & 0.000047 \\
\hline & $\frac{\partial}{\partial \text { Labour }}\left(M I E_{\text {Wage }}\right)$ & -0.000014 & -0.000014 & -0.000015 & -0.000015 & -0.000013 & -0.000013 \\
\hline \multicolumn{2}{|c|}{ Technical Inefficiency } & $23.2 \%$ & $21.9 \%$ & $15.8 \%$ & $20.9 \%$ & $20.0 \%$ & $19.8 \%$ \\
\hline
\end{tabular}

Table 6: Production elasticity (at means) and returns to scale estimates.

\begin{tabular}{lcccccc}
\hline \multicolumn{1}{c}{1994} & 1995 & 1996 & 1997 & 1998 & 1999 \\
\hline $\begin{array}{l}\text { Output } \\
\text { elasticity }\end{array}$ & & & & & & \\
\hline Land & $0.874(3.72)^{* *}$ & $0.901(2.02)^{*}$ & $0.892(2.01)^{*}$ & $0.875(4.21)^{* *}$ & $0.876(4.79)^{* *}$ & $0.898(1.99)^{*}$ \\
Seed & $0.025(2.05)^{*}$ & $0.010(1.79)$ & $0.033(2.54)^{* *}$ & $0.041(1.71)$ & $0.055(1.98)^{*}$ & $0.031(2.02)^{*}$ \\
Fertilizer & $0.134(2.78)^{* *}$ & $0.129(2.59)^{* *}$ & $0.129(2.64)^{* *}$ & $0.134(3.03)^{* *}$ & $0.132(2.03)^{*}$ & $0.132(2.01)^{*}$ \\
Labour & $-0.048(2.05)^{*}$ & $-0.049(2.02)^{*}$ & $-0.048(2.09)^{*}$ & $-0.048(2.07)^{*}$ & $-0.049(1.81)$ & $-0.050(1.77)$ \\
\hline Returns & 0.985 & 0.991 & 1.006 & 1.002 & 1.015 & 1.013 \\
to Scale & 0.915 & & & & &
\end{tabular}

$\mathrm{t}$-stats in parentheses.

** Statistically significant at 5\% level. *Statistically significant at $10 \%$ level. 
Table 1: Variables and Summary Statistics (23 districts, 1994-1999).

\begin{tabular}{|c|c|c|c|c|c|c|c|}
\hline Variable & Description & $\begin{array}{l}1994 \\
\text { Mean } \\
\text { (SD) }\end{array}$ & $\begin{array}{l}1995 \\
\text { Mean } \\
(\text { SD) }\end{array}$ & $\begin{array}{c}1996 \\
\text { Mean } \\
(\mathrm{SD})\end{array}$ & $\begin{array}{l}1997 \\
\text { Mean } \\
(\text { SD) }\end{array}$ & $\begin{array}{l}1998 \\
\text { Mean } \\
(\text { SD) }\end{array}$ & $\begin{array}{c}1999 \\
\text { Mean } \\
(\text { SD) }\end{array}$ \\
\hline Output $(q)$ & Total production of Aus (in tonnes). & $\begin{array}{c}73,222.65 \\
(47,106.69)\end{array}$ & $\begin{array}{c}77,855.22 \\
(43,408.28)\end{array}$ & $\begin{array}{c}72,870.43 \\
(44,956.88)\end{array}$ & $\begin{array}{l}71,556.25 \\
(50,451.77)\end{array}$ & $\begin{array}{c}71,002.31 \\
(48,971.81)\end{array}$ & $\begin{array}{c}70,256.27 \\
(47,922.65)\end{array}$ \\
\hline $\operatorname{Area}\left(x_{1}\right)$ & Total land area (in hectares) under cultivation of Aus. & $\begin{array}{c}71,780.09 \\
(47,423.31)\end{array}$ & $\begin{array}{c}71,861.26 \\
(52,958.36)\end{array}$ & $\begin{array}{c}67,089.83 \\
(50,433.45)\end{array}$ & $\begin{array}{c}66,381.88 \\
(49,771.22)\end{array}$ & $\begin{array}{c}66,122.82 \\
(52,173.01)\end{array}$ & $\begin{array}{c}65,229.13 \\
(49,453.05)\end{array}$ \\
\hline Seed $\left(x_{2}\right)$ & Improved seeds (in tonnes) of Aus rice. & $\begin{array}{l}21.759 \\
(38.89)\end{array}$ & $\begin{array}{l}21.15 \\
(24.41)\end{array}$ & $\begin{array}{c}18.52 \\
(20.90)\end{array}$ & $\begin{array}{c}19.56 \\
(22.11)\end{array}$ & $\begin{array}{c}17.24 \\
(22.54)\end{array}$ & $\begin{array}{c}20.21 \\
(23.97)\end{array}$ \\
\hline Fertilizer $\left(x_{3}\right)$ & Chemical fertilizer (in tonnes). & $\begin{array}{c}21,265.91 \\
(22,306.99)\end{array}$ & $\begin{array}{c}13,075.24 \\
(21,173.52)\end{array}$ & $\begin{array}{c}12,961.94 \\
(23,916.28)\end{array}$ & $\begin{array}{c}20,167.22 \\
(22,100.05)\end{array}$ & $\begin{array}{c}17,177.59 \\
(21,966.13)\end{array}$ & $\begin{array}{c}19,123.04 \\
(21,644.83)\end{array}$ \\
\hline Labour $\left(x_{4}\right)$ & $\begin{array}{l}\text { Working days (in 000) of total labour during cropping } \\
\text { season. }\end{array}$ & $\begin{array}{c}137 \\
(29.11)\end{array}$ & $\begin{array}{c}142 \\
(31.29)\end{array}$ & $\begin{array}{c}139 \\
(31.04)\end{array}$ & $\begin{array}{c}136 \\
(35.25)\end{array}$ & $\begin{array}{c}144 \\
(27.89)\end{array}$ & $\begin{array}{c}149 \\
(29.67)\end{array}$ \\
\hline Head dummy $\left(z_{3}\right)$ & 1 if district is a divisional headquarter, 0 otherwise. & - & & - & - & - & - \\
\hline Rain intensity $\left(z_{4}\right)$ & $\begin{array}{l}\text { Cropping season average rainfall (in } \mathrm{mm} \text { ) for } 1 \% \\
\text { humidity. }\end{array}$ & $\begin{array}{c}2.30 \\
(0.95)\end{array}$ & $\begin{array}{c}3.34 \\
(1.15)\end{array}$ & $\begin{array}{c}3.64 \\
(1.28)\end{array}$ & $\begin{array}{c}3.89 \\
(1.22)\end{array}$ & $\begin{array}{c}3.16 \\
(1.09)\end{array}$ & $\begin{array}{c}2.09 \\
(1.78)\end{array}$ \\
\hline Zone dummy $\left(z_{5}\right)$ & $\begin{array}{l}1 \text { if district has } \leq 10 \text { meters altitude from sea level, } 0 \\
\text { otherwise. }\end{array}$ & - & & & - & - & - \\
\hline Wage $\left(z_{6}\right)$ & $\begin{array}{l}\text { Cropping season daily average wage per worker (in BD } \\
\text { taka). }\end{array}$ & $\begin{array}{l}35.34 \\
(7.50)\end{array}$ & $\begin{array}{l}39.08 \\
(7.90)\end{array}$ & $\begin{array}{l}45.27 \\
(7.59)\end{array}$ & $\begin{array}{l}46.94 \\
(7.28)\end{array}$ & $\begin{array}{l}49.20 \\
(7.77)\end{array}$ & $\begin{array}{l}51.33 \\
(7.13)\end{array}$ \\
\hline Bullock $\left(z_{9}\right)$ & Working days (in 000) of cattle and buffalo holdings. & $\begin{array}{c}89 \\
(33.26)\end{array}$ & $\begin{array}{c}71 \\
(27.22)\end{array}$ & $\begin{array}{c}73 \\
(29.56)\end{array}$ & $\begin{array}{c}72 \\
(30.74)\end{array}$ & $\begin{array}{c}77 \\
(31.09)\end{array}$ & $\begin{array}{c}87 \\
(28.51)\end{array}$ \\
\hline
\end{tabular}




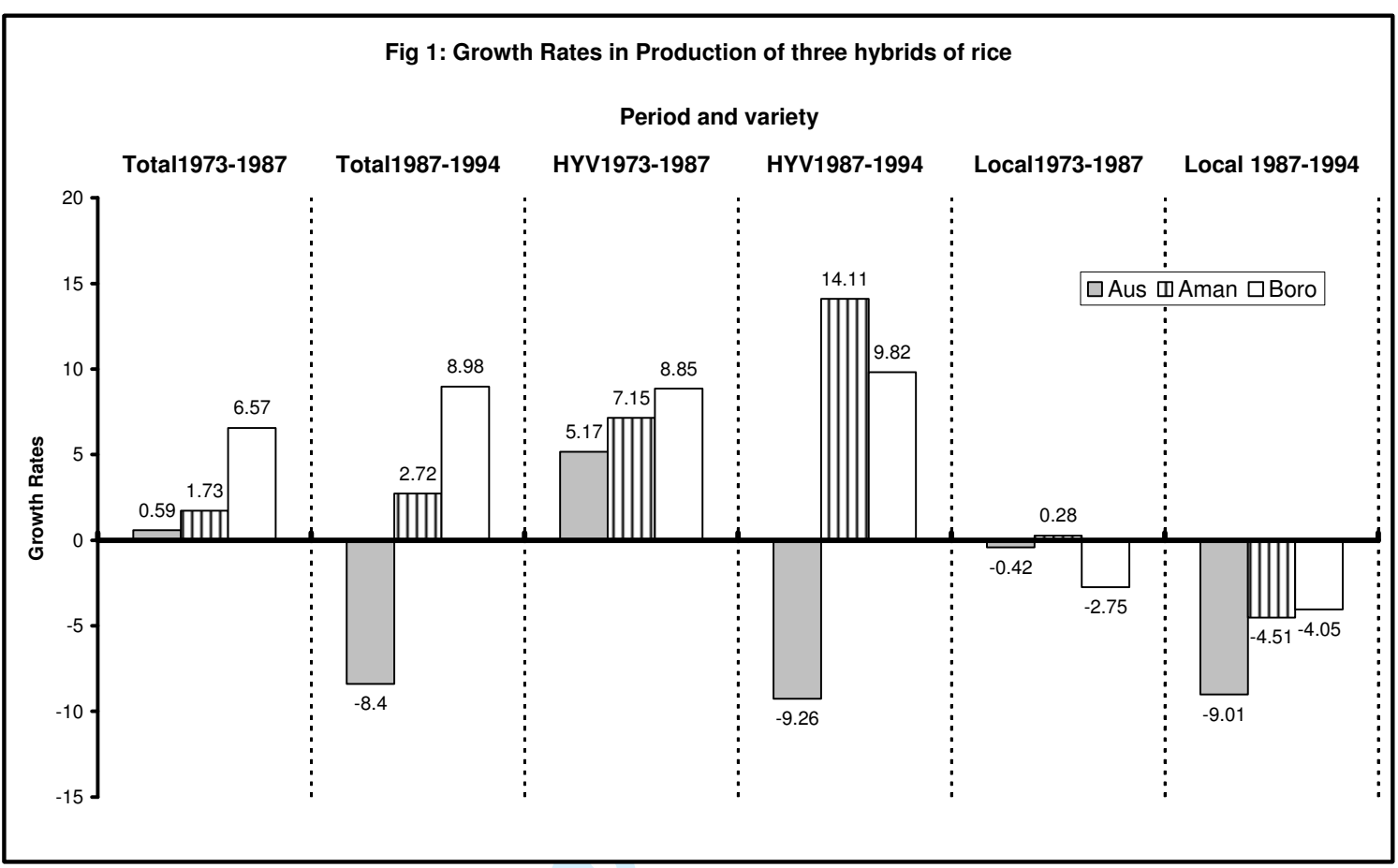

Source: Baffes and Gautam (1996).

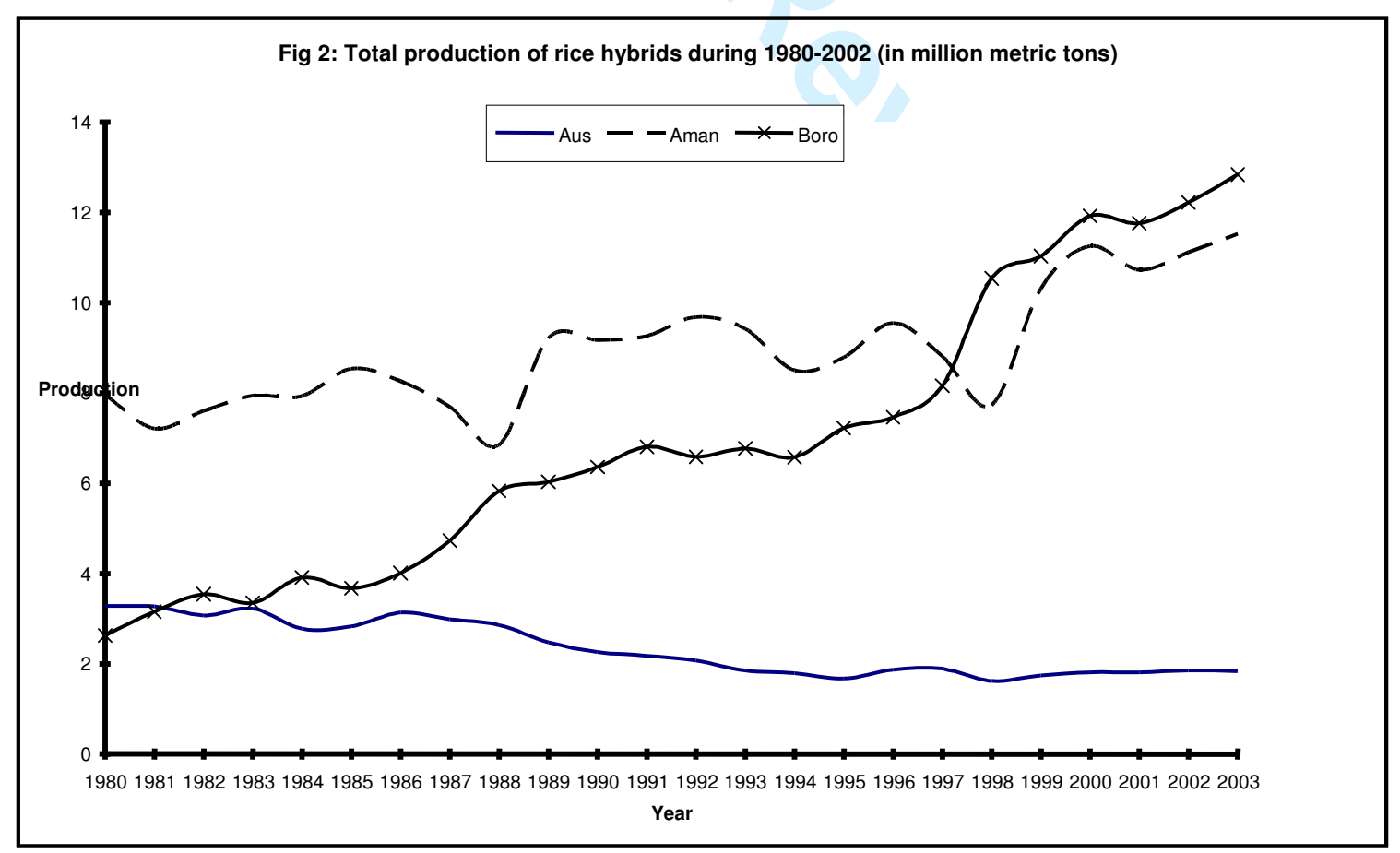

Source: Agricultural Statistical Yearbook of Bangladesh. 